\title{
Seed Bank Density and Weed Flora Dynamics of Bindweed (Convolvulus arvensis) as Affected by Different Tillage Systems in Rainfed Wheat (Triticum aestivum)
}

\author{
Safdar Ali ${ }^{1 *}$, Muhammad Azim Malik ${ }^{1}$, Muhammad Ansar ${ }^{1}$, Ghulam Qadir ${ }^{1}$ and Rahmatullah Qureshi ${ }^{2}$ \\ ${ }^{1}$ Department of Agronomy, Pir Mehr Ali Shah, Arid Agriculture University, Rawalpindi, Pakistan \\ ${ }^{2}$ Department of Botany, Pir Mehr Ali Shah, Arid Agriculture University, Rawalpindi, Pakistan \\ *For Correspondence: safdaraliarid@yahoo.com; safdarali@uaar.edu.pk
}

\begin{abstract}
Field bindweed (Convolvulus arvensis L.) is a troublesome weed of rainfed areas. Seed bank density, weed population dynamics and crop productivity were studied in wheat crop under different tillage treatments in a field experiment carried out during summer and winter seasons of 2012-2013 and 2013-2014. Different combinations of tillage, integrated with glyphosate herbicide were used in the fallow period (summer season). Results showed that tillage systems along with glyphosate in summer season controlled the establishment of seed bank density as observed in conventional tillage treatment. There was a positive and very week correlation between tillage intensity and seed bank density of $C$. arvensis L. Similarly the weed population dynamics with reference to importance value index of weed was minimum in 1 Disc harrowing +4 cultivations that was not significantly different from no-till + glyphosate. Tillage intensity integrated with glyphosate showed negligible but negative correlation with the weed population dynamics. In crux, no tillage integrated with glyphosate is recommended for economical reduction of seed bank density and weed population of field bindweed in rainfed wheat areas. (C) 2016 Friends Science Publishers
\end{abstract}

Keywords: Deep tillage; Glyphosate; No-tillage; Field bindweed; Wheat

\section{Introduction}

Wheat (Triticum aestivum L.) being staple food of millions of peoples is a major winter crop of rainfed areas of Pakistan (Hayat and Ali, 2010). In 2014, it contributed 2.2\% to GDP and $10.3 \%$ to the value addition in the agriculture of Pakistan (GOP, 2014). In Punjab, it was grown on an area of $9.039 \mathrm{~m}$ ha with production of $25.3 \mathrm{~m}$ tones having average yield of $2.797 \mathrm{t} \mathrm{ha}^{-1}$; whereas, in rainfed areas, it was cultivated on an area of $0.5491 \mathrm{~m}$ ha with production of $0.4313 \mathrm{~m}$ tones having average yield of $1.005 \mathrm{t} \mathrm{ha}^{-1}$ in Punjab Province (GOP, 2013).

It is reported that wheat can yield more than $2.965 \mathrm{t}$ ha $^{-1}$ in rainfed areas (Ashraf et al., 2007). However, average per hectare yield remains extremely low due to scarce soil moisture, low soil fertility and dense weed infestation (Razzaq et al., 2002; Naz et al., 2010; Ahmad et al., 2011). According to a survey, $28.8 \%$ of the farmers reported weeds as a major problem of wheat crop and $29 \%$ wheat yield can be increased by controlling weeds (Khan et al., 2011).

Among different weed species of rainfed areas, field bindweed (Convolvulus arvensis L.) is troublesome and to eradicate it repeated tillage remains insufficient (JuradoExposito et al., 2005). Just like other weeds it competes with crop plants for moisture, sunlight and nutrients. It's deep and extensive root system assimilates carbohydrates and proteins, which support it to sprout repeatedly from fragments and rhizomes even after removal of aboveground vegetation, therefore, it is difficult to eradicate this weed (Liebman et al., 2001).

Various weed control methods are being practiced to eliminate weeds in various crops in rainfed areas. Tillage is often used as a weed control system but with the development and widespread adoption of minimum and zero-tillage systems the effects of tillage on weed dynamics are becoming more important and weeds management problem is more expected in zero-till and reduced tillage systems (Ali et al., 2014). Although, conservation tillage conserves soil moisture, protects soil from erosion, increases the amount of rain harvested moisture and decreases soil evaporation (Gencsoylu and Yalcin, 2004). But weeds are still a big threat to adaptation of these tillage systems. In a study, Rusu et al. (2006) observed highest population of $C$. arvensis in minimum tillage system whereas; increase in the frequency of perennial weeds has been reported in no tilled fields for more than one year (Kobayashi et al., 2003). However, perennial weeds are significantly declined under conventional tillage (Demjanova et al., 2009). Moreover, 
tillage systems significantly affect the composition of weed flora and weed biomass. Jurado-Exposito et al. (2005) reported that the population growth rate of $C$. arvensis has a moderate degree of aggregation in patches that does not remain stable temporally. Keeping in view, weed population dynamics of $C$. arvensis under different tillage systems in our agro-ecological system of Pothwar Region in Pakistan seems to be very much important to design its future weed management strategies. Therefore, the objective of this study was to assess the effect of different tillage systems alone or integrated with glyphosate (a non-selective herbicide) applied at fallow period on seed bank and the population dynamics of $C$. arvensis under rainfed conditions in wheat. Ultimately, these findings could be used in future for better weed management strategies in rainfed areas.

\section{Materials and Methods}

\section{Experimental Site and Design}

The proposed study was conducted on sandy loam soil of Udic Haplustalfs group at Research Farm of Arid Agriculture University Rawalpindi (latitude $33^{\circ} \mathrm{N}$, longitude $73^{\circ}$ and altitude 500 masl), Pakistan. The experiment was carried out for two years during the summer and winter seasons of 2012-2013 and 2013-2014.The experimental soil possesses following properties $\left(\mathrm{EC}=0.92 \mathrm{dS} \mathrm{cm}^{-1} ; \mathrm{pH}=\right.$ 7.20; organic matter $=0.63 \%$; saturation percentage $=36 \%$; available phosphorus $=5.32 \mathrm{mg} \mathrm{kg}^{-1}$; available potassium $=$ $100 \mathrm{mg} \mathrm{kg}^{-1}$ ). To select a representative and weed infested field, the experimental area was surveyed one year before experiment. Seed of wheat cv. Chakwal-50 (high yielding, drought tolerant and disease resistant) obtained from Barani Agricultural Research Institute Chakwal was sown on October 23, in 2012 and on October 28, in 2013 in $22.5 \mathrm{~cm}$ apart rows. N-P-K fertilizers were applied at the rate of 90$60-60 \mathrm{~kg} \mathrm{ha} \mathrm{ha}^{-1}$ respectively using urea $(46 \% \mathrm{~N})$, diammonium phosphate (DAP) $\left(18 \% \mathrm{~N}, 46 \% \mathrm{P}_{2} \mathrm{O}_{5}\right)$ and sulfate of potash $\left(50 \% \mathrm{~K}_{2} \mathrm{O}\right)$ as sources respectively. Whole phosphorus and potash was applied at the time of seed bed preparation but nitrogen was applied in two splits, first at sowing and second at tillering stage (as per availability of rainfall). The experiment was laid out in randomized complete block design having four replications with a net plot size of $13.5 \mathrm{~m} \times 13.5 \mathrm{~m}$.

\section{Experimental Treatments}

Different combinations of tillage, integrated with glyphosate herbicide were used in this study. The experiment consisted of following treatment combinations viz. $\mathrm{T}_{1}=1 \mathrm{MB}$ plowing +8 cultivations, $\mathrm{T}_{2}=1 \mathrm{MB}$ plowing +4 cultivations, $\mathrm{T}_{3}=1$ disc harrowing +4 cultivations, $\mathrm{T}_{4}=1$ chisel plowing + glyphosate, $\mathrm{T}_{5}=1 \mathrm{MB}$ plowing + glyphosate, $\mathrm{T}_{6}=1$ disc harrowing + glyphosate, $\mathrm{T}_{7}=$ no-till + glyphosate.
In first treatment, deep tillage with moldboard plough at the onset of moon soon was done followed by eight shallow cultivations with cultivator applied after each rainfall including seedbed preparation. Likely, in second treatment, one moldboard plowing was done at the onset of monsoon followed with four cultivations including preparatory tillage. In third treatment, disc-harrowing was applied after the $1^{\text {st }}$ flush of weeds followed by four cultivations including preparatory tillage. Likely, in fourth treatment, one chisel plowing was done before the onset of monsoon and then fallow period weeds were controlled with two applications of glyphosate when needed. In fifth treatment moldboard plowing was done at monsoon initiation and then onward, the weeds were controlled by spraying twice glyphosate when needed. Disc-harrowing was done at the $1^{\text {st }}$ flush of weeds after monsoon rains and the fallow period weeds were controlled by using glyphosate two times as per requirement in sixth treatment. In seventh treatment, no-tillage practice was done before seeding of crop, but the weeds during fallow period were controlled with two applications of a non-selective herbicide (glyphosate). The glyphosate (Round up) was applied at the rate of $2.5 \mathrm{~L}$ per hectare in each case. Sowing was done with conventional seed-cum-fertilizer drill in other than conservation tillage treatments whereas, wheat was sown by direct drilling with no-till drill in all conservation tillage treatments.

\section{Seed Bank Density}

For reference collection seeds of different weeds were collected from experimental area and its surroundings one year before the experiment. Seed bank density of $C$. arvensis was determined with sieving method. For this purpose sampling of the soil was carried out before the sowing of wheat crop in $\mathrm{W}$ shape from five places randomly in a plot from three soil depths i.e. $0-10 \mathrm{~cm}, 10-20 \mathrm{~cm}$ and 20-30 cm. Soil samples were taken by using steel probe of $2.5 \mathrm{~cm}$ diameter. The soil cores of same depth were bulked and mixed to make composite soil samples. One $100 \mathrm{~g}$ weight of each sample was used as working sample from these composite soil samples for the determination of soil weed seed bank. The soil samples were then transported to laboratory and stored at room temperature until further processing. In sieving method, seeds were extracted from soil by sieving of soil sample through various sieves with different mesh sizes using method adopted by (Konstantinović et al., 2011). Each 100 gram soil sample was initially poured on sieve of 80 mesh size and placed in water for softening the soil clods. The sample was then immersed in the sodium hexa-metaphosphate solution $(40 \mathrm{~g}$ $\mathrm{L}^{-1}$ of water) in order to disintegrate the soil particles. The soil samples were shifted to the bucket having tap water and shaked well to filter out all clay and silt particles and removed from sample. The remaining material on the sieves was air dried and transferred on the filter paper for complete 
drying of samples. These dried samples were then passed through a descending series of sieves i.e. mesh no. 10, 18, 30, 40, 50 and 80. Entire seeds remained on the sieves were collected for identification and further processing. Viability of seeds was determined by using crushing method, i.e. by applying gentle pressure to the seeds with the help of forceps and seeds showing resistance to this pressure were considered as viable. Viable seeds extracted from soil were compared with the reference seeds to identify seeds using high magnification lens (10X) and seeds of each species were counted.

\section{Weed Population Dynamics}

Weed population dynamics of $C$. arvensis were found through the integrated use of different weed indices (Stapper et al., 2003; Devasenapathy, 2008; Qureshi and Memon, 2008; Gupta et al., 2011; Hassannejad and Ghafarbi, 2012). Absolute density per square meter of $C$. arvensis was recorded by dividing total number of plants in all quadrats to the total number of quadrats studied. Absolute frequency was recorded by dividing number of quadrats in which $C$. arvensis was present to the total number of quadrats studied. Absolute dry weight per square meter was recorded by dividing dry weight of all plants of $C$. arvensis in all quadrats to the total number of quadrats studied. Absolute coverage was recorded by dividing percent area covered by all plants of $C$. arvensis in all quadrats to the total number of quadrats studied. Relative density was recorded by dividing number of plants of $C$. arvensis per unit area to the number of plants of all weed species per unit area, multiplied by 100. Relative frequency was recorded by dividing absolute frequency of $C$. arvensis in a plot to the absolute frequency of all weed species in a plot multiplied by 100 . Relative dry weight was recorded by dividing the dry weight per unit area of $C$. arvensis to the dry weight per unit area of all weed species multiplied by 100 . Relative coverage was recorded by dividing percent area covered by $C$. arvensis per unit area to the percent area covered by all species per unit area multiplied by 100 . Relative abundance (RA) was determined by summing up the relative density with relative frequency and then dividing the product by 2 . Summed dominance ratio (SDR) was recorded by summing up the relative density with the relative dry weight and then dividing the product by 2 . Importance value index (IVI) was recorded by summing up the relative density with relative frequency and relative coverage and then dividing its product by 3 .

\section{Statistical Analysis}

Data collected on all parameters were analyzed statistically by using MSTAT-C software on computer (Crop and Soil Sciences Department of Michigan University of the United States). Least significance difference (LSD) test at 5\% probability level was applied to compare the treatments means (Steel et al., 1997). Meteorological data are presented in Fig. 1.

\section{Results}

Seed bank density of $C$. arvensis was significantly affected by tillage systems, sowing years and soil depths. Lowest seed bank density of $C$. arvensis was found for single mould board ploughing integrated with glyphosate (1 MB plowing + glyphosate) which was significantly similar for no tilled treatments applied with glyphosate (No-till + glyphosate) and single MB ploughing following cultivation four times (1 MB plowing +4 cultivations). Seed bank density was found highest for single disc harrowing integrated with glyphosate (1 Disc harrowing + glyphosate) followed by single disc harrowing following cultivation four times (1 Disc harrowing +4 cultivations), single MB ploughing following cultivation four times ( $1 \mathrm{MB}$ Plowing +4 cultivations) and single chisel plowing integrated with glyphosate (1 Chisel Plowing + glyphosate) (Table 1; Fig. 2a, b). Among sowing years, overall average seed bank density was significantly higher in 2012-2013 (2028.0) as compared with 2013-2014 (1463.2); while, for soil depths, maximum seed density of C. arvensis was found at $0-10 \mathrm{~cm}$ soil depth followed by $10-20 \mathrm{~cm}$ and minimum under $20-30 \mathrm{~cm}$ depth which were significantly different from each other in both years (Table 1; Fig. 3, 4). The interaction between tillage systems, soil depths and sowing years was also significant. Highest seed bank density of $C$. arvensis was found at 0-10 $\mathrm{cm}$ soil depth during 2012-2013, where once disc harrowing was practiced integrated with glyphosate (1 Disc harrowing + glyphosate); whereas, it was lowest at 20-30 cm soil depth during 2013-2014, where once MB plowing was practiced following cultivations four times (1 MB + 4 cultivations). The regression between tillage systems and seed density depicted that the seed bank density of $C$. arvensis was not affected significantly by tillage combinations when integrated with glyphosate herbicide at fallow period (Fig. 5). There was a very week and positive correlation among tillage intensity and soil weed seed bank (Table 3). The seed bank was a little bit negatively affected by conservation tillage integrated with glyphosate herbicide. Similarly, maximum weed flora density of $C$. arvensis was recorded for single chisel plowing integrated with glyphosate (1 chiseling + glyphosate) and minimum for single mould board plowing following cultivations four times (1 MB plowing +8 cultivations) followed by treatment, where no tillage was practiced integrated with glyphosate (no till + glyphosate) (Table 2 ). The regression between tillage systems and the density of $C$. arvensis flora depicted that the density of $C$. arvensis was not affected significantly by tillage combinations integrated with glyphosate herbicide at fallow period (Fig. 6). There was a very poor and negative correlation among tillage intensity and weed flora density (Table 3). Similarly, maximum relative density of weed was found for single MB ploughing 
integrated with glyphosate (1 MB plowing + glyphosate) and minimum for single disc harrowing following cultivations four times ( 1 disc harrowing +4 cultivations) (Table 2). Likewise, maximum frequency of field bindweed was recorded for single $\mathrm{MB}$ ploughing integrated with glyphosate (1 MB + glyphosate) and minimum for single MB ploughing following cultivations eight times (1 MB plowing +8 cultivations) (Table 2). Maximum dry weight of $C$. arvensis was recorded for single chisel ploughing integrated with glyphosate (1chiseling + glyphosate) and minimum for single MB ploughing following cultivations eight times (1 MB plowing +8 cultivations) followed by single disc harrowing following cultivations four times (1 disc harrowing +4 cultivations). In comparison to other weed species, highest dry weight of $C$. arvensis was found for the treatment where no tillage was practiced applied with glyphosate (no-till + glyphosate) as compared to other treatments (Table 2). Minimum dry weight of $C$. arvensis in comparison with other species was found for single MB ploughing following cultivations eight times (1 MB plowing +8 cultivations). Data on soil coverage revealed that $C$. arvensis spread was profound on the soil surface in treatment, where single chisel ploughing was practiced integrated with glyphosate (1chiseling + glyphosate) followed by single MB ploughing following cultivations four times (1 MB plowing + 4 cultivations); and minimum was observed for single $\mathrm{MB}$ ploughing following cultivations eight times (1 MB plowing +8 cultivations). In comparison to other weed species, relatively the maximum soil area was covered by $C$. arvensis for single $\mathrm{MB}$ ploughing following cultivations four times (1 MB plowing +4 cultivations) followed by single $\mathrm{MB}$ ploughing integrated with glyphosate (1 MB plowing + glyphosate) and single disc harrowing integrated with glyphosate (1 disc harrowing + glyphosate); while, relatively minimum surface was covered by field bind weed in single chisel ploughing integrated with glyphosate (1 chiseling + glyphosate). The maximum summed dominance ratio (SDR) of $C$. arvensis was found for single $\mathrm{MB}$ ploughing integrated with glyphosate (1 MB plowing + glyphosate) followed by single MB ploughing following cultivations four times (1 MB plowing +4 cultivations) and single chisel ploughing integrated with glyphosate (1 chiseling + glyphosate); whereas, the minimum SDR was found for single disc harrowing following cultivations four times (1disc harrowing +4 cultivations) and single disc harrowing integrated with glyphosate (1 disc harrowing + glyphosate). The importance value index (IVI) of C. arvensis was significantly affected by tillage intensity and it was maximum for single $\mathrm{MB}$ ploughing integrated with glyphosate (1 MB plowing + glyphosate) followed by single MB ploughing following cultivations four times (1 MB plowing +4 cultivations) and single chisel ploughing integrated with glyphosate (1 chiseling + glyphosate); whereas, the minimum IVI was recorded for single disc harrowing following cultivations four times (1 Disc

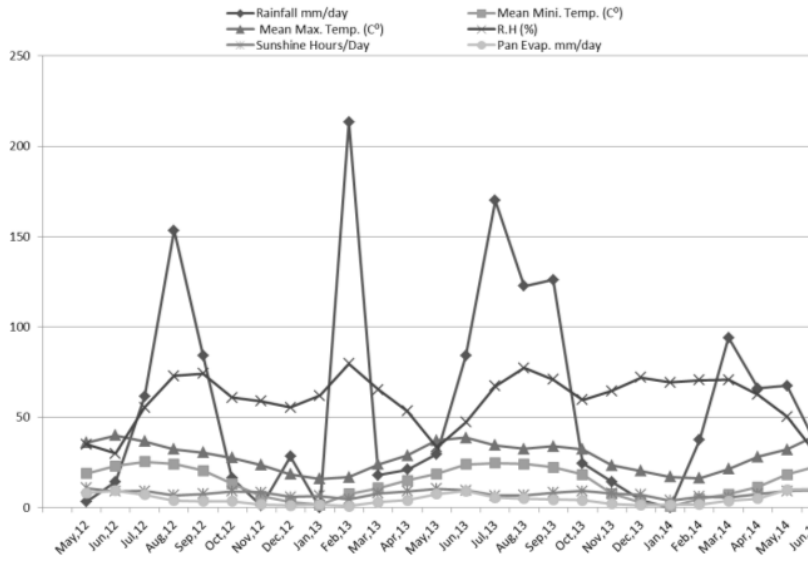

Fig. 1: Meteorological data of the experimental site during study period; Source (Meteorological Observatory, Soil And Water Conservation Research Institute, Chakwal)

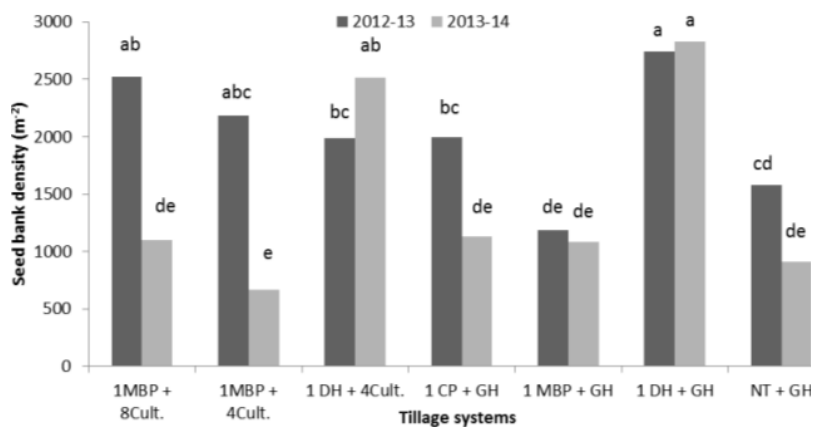

Fig. 2a: Seed bank density of $C$. arvensis at pre-sowing of wheat under different tillage systems and sowing years

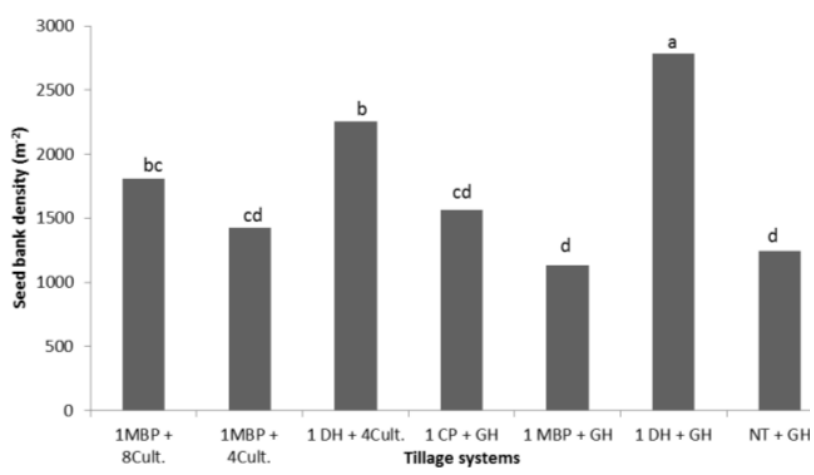

Fig. 2b: Seed bank density of $C$. arvensis at pre-sowing of wheat under different tillage systems (pooled for two years)

harrowing +4 cultivations) that was not significantly different from the treatment where no tillage was applied integrated with glyphosate (no-till + glyphosate) (Table 2).

\section{Discussion}

This study observed the effect of tillage intensity integrated with glyphosate herbicide on the seed bank density and 
Table 1: Pre-sowing wheat seed bank density $\left(\mathrm{m}^{-2}\right)$ of $C$. arvensis as affected by different tillage systems under three soil depths

\begin{tabular}{|c|c|c|c|c|c|c|}
\hline \multirow[t]{2}{*}{ Tillage Systems } & \multicolumn{2}{|c|}{$0-10(\mathrm{~cm})$} & \multicolumn{2}{|c|}{$10-20(\mathrm{~cm})$} & \multicolumn{2}{|c|}{$20-30(\mathrm{~cm})$} \\
\hline & $2012-2013$ & $2013-2014$ & $2012-2013$ & 2013-2014 & $2012-2013$ & $2013-2014$ \\
\hline $1 \mathrm{MBP}+8$ Cult. & $4125 a b c$ & 1900 e-j & $2785 \mathrm{def}$ & $1408 \mathrm{~g}-1$ & $655 \mathrm{k}-\mathrm{m}$ & $0 \mathrm{~m}$ \\
\hline $1 \mathrm{MBP}+4$ Cult. & $3438 \mathrm{bcd}$ & $328 \mathrm{~lm}$ & $1728 \mathrm{f}-\mathrm{k}$ & $1355 \mathrm{~g}-1$ & $1383 \mathrm{~g}-1$ & $330 \mathrm{~lm}$ \\
\hline 1DH + 4 Cult. & 2968 cde & $4353 \mathrm{ab}$ & 2320 d-h & $2503 \mathrm{~d}-\mathrm{g}$ & $683 \mathrm{jm}$ & $700 \mathrm{j}-\mathrm{m}$ \\
\hline $1 \mathrm{CP}+\mathrm{GH}$ & $4013 a b c$ & $2388 \mathrm{~d}-\mathrm{g}$ & $1660 \mathrm{f}-\mathrm{k}$ & $683 \mathrm{j}-\mathrm{m}$ & $325 \mathrm{~lm}$ & $333 \mathrm{~lm}$ \\
\hline $1 \mathrm{MBP}+\mathrm{GH}$ & 1043 i-m & $1065 \mathrm{i}-\mathrm{m}$ & $1775 \mathrm{e}-\mathrm{k}$ & 1813 e-k & $740 \mathrm{j}-\mathrm{m}$ & $365 \mathrm{~lm}$ \\
\hline $1 \mathrm{DH}+\mathrm{GH}$ & $4913 \mathrm{a}$ & $4215 \mathrm{ab}$ & 2315 & 2160 e-i & $993 \mathrm{i}-\mathrm{m}$ & $2105 \mathrm{e}-\mathrm{i}$ \\
\hline $\mathrm{NT}+\mathrm{GH}$ & $2555 \mathrm{~d}-\mathrm{g}$ & $1420 \mathrm{~g}-1$ & $1110 \mathrm{~h}-1$ & $973 \mathrm{i}-\mathrm{m}$ & $1065 \mathrm{i}-\mathrm{m}$ & $335 \mathrm{~lm}$ \\
\hline
\end{tabular}

Table 2: Weed population dynamics of $C$. arvensis as affected by different tillage systems and sowing years

\begin{tabular}{|c|c|c|c|c|c|c|c|c|c|c|}
\hline \multirow[t]{2}{*}{ Tillage systems } & \multicolumn{2}{|c|}{ Density $\left(\mathrm{m}^{-2}\right)$} & \multicolumn{2}{|c|}{ R Density (\%) } & \multicolumn{2}{|c|}{ Frequency $(\%)$} & \multicolumn{2}{|c|}{ R Frequency (\%) } & \multicolumn{2}{|c|}{ Coverage $(\%)$} \\
\hline & 2012-2013 & 2013-2014 & 2012-2013 & 2013-2014 & 2012-2013 & 2013-2014 & $2012-2013$ & 2013-2014 & 2012-2013 & 2013-2014 \\
\hline $1 \mathrm{MBP}+8$ Cult. & $4.58 \mathrm{NS}$ & 1.3 & $13.75 \mathrm{ab}$ & $2.13 \mathrm{e}$ & $66.5 \mathrm{NS}$ & 50 & $13.64 \mathrm{NS}$ & 13.64 & $2.56 \mathrm{NS}$ & 0.77 \\
\hline $1 \mathrm{MBP}+4$ Cult. & 7.92 & 4.1 & $19.92 \mathrm{a}$ & 6.14 cde & 100 & 66.8 & 17.7 & 17.03 & 3.95 & 2.8 \\
\hline $1 \mathrm{DH}+4$ Cult. & 3.67 & 3.7 & $7.51 \mathrm{bcd}$ & $2.87 \mathrm{de}$ & 67 & 50 & 12.86 & 12.01 & 2.37 & 1.97 \\
\hline $1 \mathrm{CP}+\mathrm{GH}$ & 4.42 & 7.9 & $7.12 \mathrm{bcd}$ & $7.8 \mathrm{bcd}$ & 75.2 & 91.8 & 14.22 & 13.42 & 2.99 & 4.6 \\
\hline $1 \mathrm{MBP}+\mathrm{GH}$ & 7.09 & 4.5 & $19.21 \mathrm{a}$ & $12.06 \mathrm{ab}$ & 91.75 & 83.5 & 17.7 & 19.31 & 3.93 & 2.77 \\
\hline $1 \mathrm{DH}+\mathrm{GH}$ & 3.67 & 4.3 & $8.36 \mathrm{abc}$ & $5.17 \mathrm{cde}$ & 67 & 75 & 13.22 & 11.25 & 2.61 & 2.57 \\
\hline $\mathrm{NT}+\mathrm{GH}$ & 1.67 & 5.6 & 4.58 cde & $7.01 \mathrm{bcd}$ & 50 & 83.5 & 8.2 & 14.52 & 1.81 & 3.07 \\
\hline
\end{tabular}

Note: Any two means in a column showing an alphabetical letter in common do not differ significantly from each other; NS = Non-significant; $\mathrm{R}=$ Relative; SDR= Summed dominance ratio; IVI= Importance value index; $\mathrm{MBP}=$ Mouldboard ploughing; $\mathrm{DH}=\mathrm{Disc}$ harrowing; $\mathrm{CP}=\mathrm{Chisel}$ ploughing; $\mathrm{GH}=$ Glyphosate herbicide; NT = No tillage; Cult. = Cultivations

Table 2 continued: Weed population dynamics of $C$. arvensis as affected by different tillage systems and sowing years

\begin{tabular}{|c|c|c|c|c|c|c|c|c|c|c|}
\hline \multirow[t]{2}{*}{ Tillage systems } & \multicolumn{2}{|c|}{ R Coverage $(\%)$} & \multicolumn{2}{|c|}{ Dry weight (g) } & \multicolumn{2}{|c|}{ R Dry weight (\%) } & \multicolumn{2}{|c|}{ SDR (\%) } & \multicolumn{2}{|c|}{ IVI (\%) } \\
\hline & $2012-2013$ & 2013-2014 & $2012-2013$ & 2013-2014 & $2012-2013$ & 2013-2014 & $2012-2013$ & 2013-2014 & $2012-2013$ & 2013-2014 \\
\hline $1 \mathrm{MBP}+8$ Cult. & $12.66 \mathrm{NS}$ & 2.95 & $3.94 \mathrm{NS}$ & 0.65 & $7.71 \mathrm{NS}$ & 0.47 & $10.73 \mathrm{NS}$ & 1.3 & $13.35 \mathrm{ab}$ & $2.13 \mathrm{e}$ \\
\hline 1MBP + 4Cult. & 12.56 & 9.65 & 5.26 & 2.9 & 5.5 & 2.55 & 12.71 & 4.34 & $16.73 \mathrm{a}$ & $7 \mathrm{~d}-\mathrm{e}$ \\
\hline $1 \mathrm{DH}+4$ Cult. & 9 & 4.64 & 4.22 & 1.28 & 5.97 & 0.92 & 6.74 & 1.89 & $9.79 \mathrm{~b}-\mathrm{e}$ & $3.27 \mathrm{de}$ \\
\hline $1 \mathrm{CP}+\mathrm{GH}$ & 6.88 & 13.92 & 5.56 & 3.68 & 3.69 & 6.95 & 5.4 & 7.37 & $9.4 \mathrm{~b}-\mathrm{e}$ & $10.65 \mathrm{ab}$ \\
\hline $1 \mathrm{MBP}+\mathrm{GH}$ & 12.91 & 9.28 & 6.01 & 2.43 & 6.35 & 2.5 & 12.78 & 7.28 & $16.61 \mathrm{a}$ & $8.28 \mathrm{c}-\mathrm{e}$ \\
\hline $1 \mathrm{DH}+\mathrm{GH}$ & 7.09 & 6.58 & 5.02 & 2.08 & 3.3 & 2.53 & 5.83 & 3.85 & $9.55 \mathrm{~b}-\mathrm{e}$ & $5.21 \mathrm{de}$ \\
\hline $\mathrm{NT}+\mathrm{GH}$ & 8.4 & 8.05 & 4.36 & 2.08 & 7.86 & 3.13 & 6.22 & 5.07 & $7.06 \mathrm{cde}$ & $6.56 \mathrm{cde}$ \\
\hline
\end{tabular}

Note: Any two means in a column showing an alphabetical letter in common do not differ significantly from each other; NS = Non-significant; $\mathrm{R}=$ Relative; $\mathrm{SDR}=$ Summed dominance ratio; IVI= Importance value index; $\mathrm{MBP}=$ Mouldboard ploughing; $\mathrm{DH}=\mathrm{Disc}$ harrowing; $\mathrm{CP}=\mathrm{Chisel}$ ploughing; $\mathrm{GH}=$ Glyphosate herbicide; NT = No tillage; Cult. = Cultivations

Table 3: Correlations

\begin{tabular}{|c|c|c|c|}
\hline & GY & SB & TI \\
\hline SB & -0.2941 & & \\
\hline P-VALUE & 0.5220 & & \\
\hline \multirow[t]{2}{*}{ TI } & 0.7339 & 0.0151 & \\
\hline & 0.0604 & 0.9744 & \\
\hline \multirow[t]{2}{*}{ WF } & -0.2651 & -0.4563 & -0.0098 \\
\hline & 0.5657 & 0.3034 & 0.9833 \\
\hline
\end{tabular}

weed flora population dynamics of $C$. arvensis. The results showed that the tillage treatments along with glyphosate herbicide and alone applied in fallow period had similar relationship with seed bank density. The possible reason for this effect of tillage systems on seed bank may be attributed to the reduction of seed bank density of field bindweed in conventional tillage due to frequent plowings and resultantly maximum seed germinations in rainy seasons because the repeated tillage operations might have brought the seeds of field bind weed near the soil surface which emerged rapidly due to more soil aeration and availability of sunlight (Cardina et al., 2002). The reduction of seed bank in conservation tillage may be the effect of glyphosate herbicide on the population of field bind weed which ultimately reduced/diminished the seed setting thus resulting in less seed dispersal per unit area (Rusu et al., 2013; Ali et 


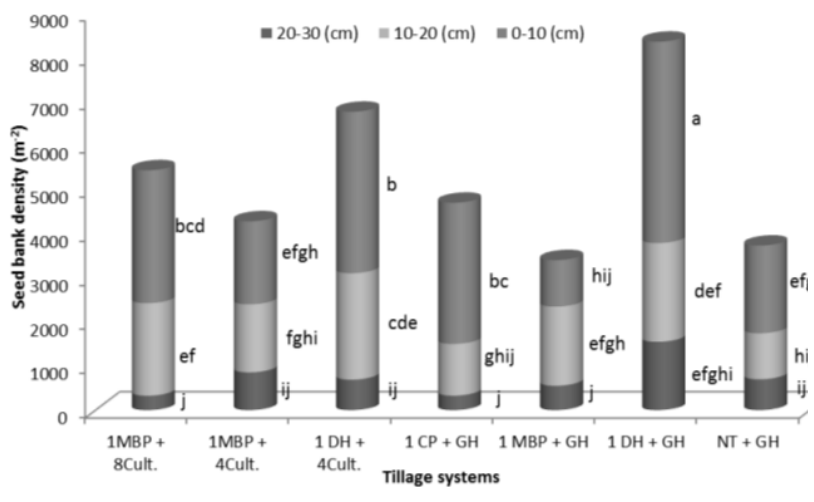

Fig. 3: Seed bank densities of $C$. arvensis in three depths of soil (i.e D1 $=0-10, \mathrm{D} 2=10-20, \mathrm{D} 3=20-30 \mathrm{~cm}$ ) under seven tillage treatments at pre-sowing of wheat (pooled data of two years)

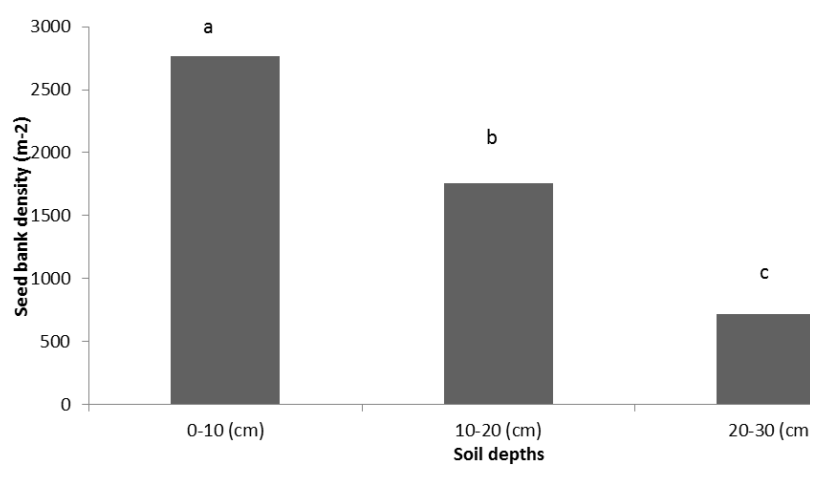

Fig. 4: Total seed bank density of $C$. arvensis under three soil depths

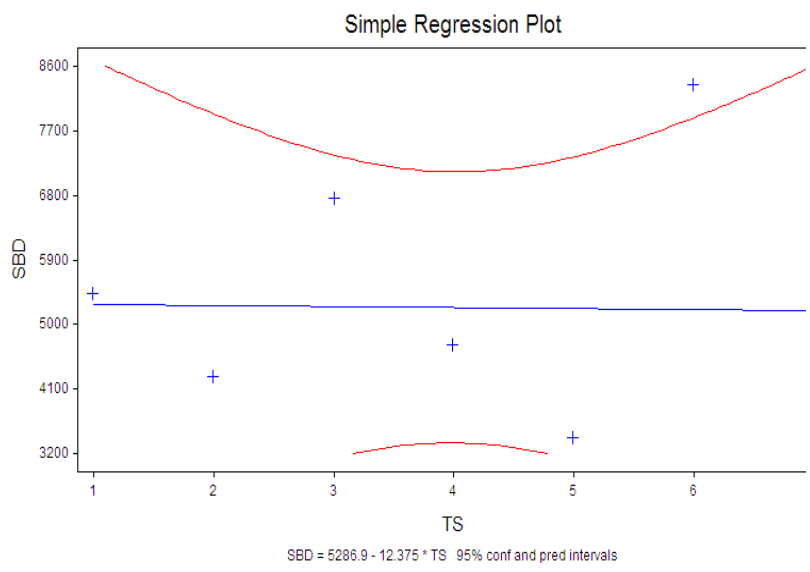

Fig. 5: Effect of tillage treatments on the seed bank density of $C$. arvensis

al., 2014). A very week and positive correlation between tillage intensity and soil weed seed bank of field bind weed found (Table 3; Fig. 5) suggest that glyphosate herbicide controlled this weed without spending a huge amount on intensive cultivation that was considered necessary for uprooting this weed. Seed bank was considerably reduced in

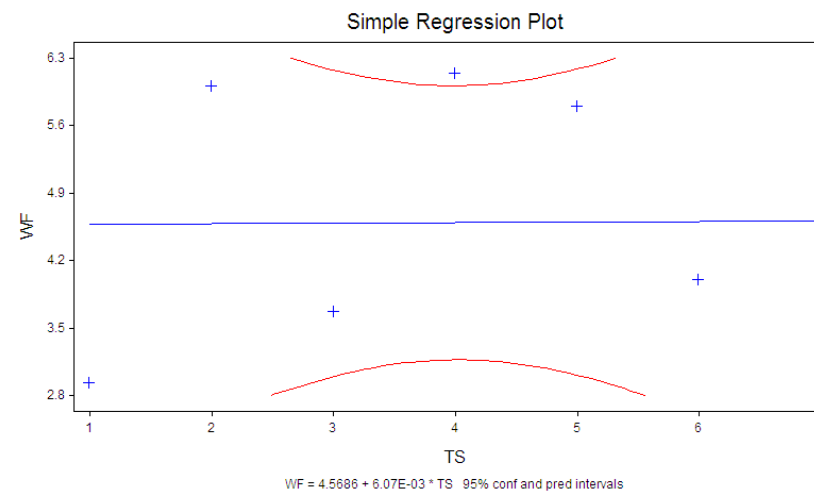

Fig. 6: Effect of tillage treatments on the above ground weeds flora density of $C$. arvensis

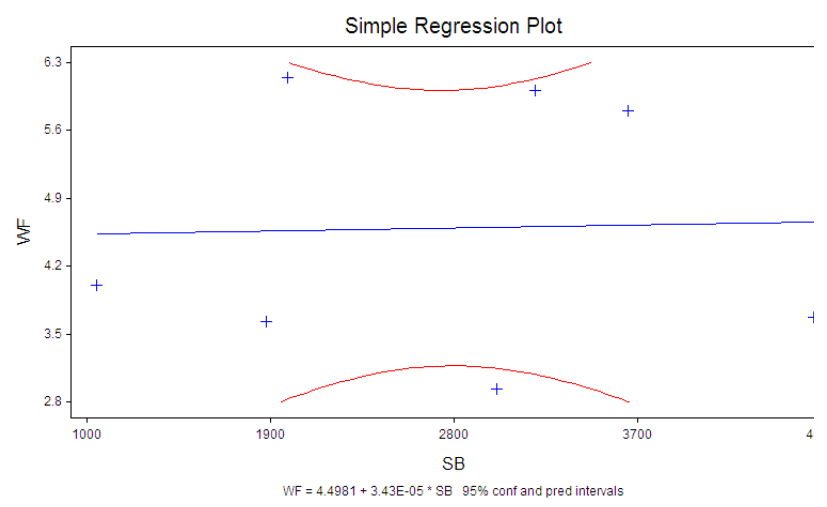

Fig. 7: Relationship between seed bank of $0-10 \mathrm{~cm}$ soil depth and above ground weed flora density

$2^{\text {nd }}$ year of study that may be attributed to the control of weeds under conservation tillage treatments integrated with glyphosate and comparatively higher germination of weed seeds in 2012-2013 that was probably due to higher rainfall in the early growing season of this year (Fig. 1 Ali et al. (2014). Relationship between the above ground flora density and seed bank of upper soil depth i.e. $0-10 \mathrm{~cm}$ (Fig. 7) was also weak suggesting that the seed in upper soil depth in conventional tillage had maximum germination whereas, the seed bank could not germinate well in upper soil depth in conservation tillage treatments (Cardina et al., 2002).

There was no significant effect of tillage treatments on the weed flora density of field bind weed that may be attributed to its control by intensive cultivation in conventional tillage and use of glyphosate herbicide in the conservation tillage treatments (Table 2; Fig. 6; Wiese et al. (1996); but the weed flora population was significantly reduced in the $2^{\text {nd }}$ year of study that may be attributed to the use of glyphosate herbicide in the conservation tillage treatments and climatic effect on the germination of weeds, as there was significant variation in the weather data of two sowing years especially with reference to rainfall at the early growing period of wheat (Fig. 1. Ali et al. (2014) Maximum frequency of field bind was recorded in $1 \mathrm{MB}$ plowing + glyphosate; and minimum in $1 \mathrm{MB}$ plowing +8 
cultivations in the conventional tillage may be attributed to intensive cultivation, which provided control of the weed flora efficiently (Usman et al., 2009; Ali et al., 2014).

Maximum dry weight of $C$. arvensis was recorded in 1 chiseling + glyphosate and minimum dry weight in $1 \mathrm{MB}$ plowing +8 cultivations might also be attributed to the intensive cultivation under this tillage treatment where well established crop suppressed the field bind weed at vegetative growth stage. Data on soil coverage revealed that C. arvensis dispersed profoundly on the soil surface in the treatment 1 chiseling + glyphosate, while minimum spreading was observed in $1 \mathrm{MB}$ plowing +8 cultivations confirms the suppressing of this weed under wellestablished crop in conventional tillage. The minimum IVI in 1 Disc harrowing +4 cultivations and No-till + glyphosate strongly suggests that $C$. arvensis could not be established in zero tillage (Wiese et al., 1996; Ali et al., 2014).

\section{Conclusion}

Conservation tillage system with no-till along with integrated use of glyphosate herbicide must be adopted for economical $C$. arvensis weed control under similar soil and climatic conditions while considering the economic, agronomic, and environmental impacts of these systems.

\section{Acknowledgments}

This research project has been sponsored by HEC through 5000 Indigenous PhD Fellowship Program Phase VII; therefore, the corresponding author is cordially thankful to Higher Education Commission of Pakistan (HEC) on funding for this research study.

\section{References}

Ahmed, M., F.U. Hassan, M. Aslam and M.A. Aslam, 2012. Physiological attributes based resilience of wheat to climate change. Int. J. Agric. Biol., 14: 407-412

Ali, S., M.A. Malik, M. Ansar and R. Qureshi, 2014. Weed growth dynamics associated with rainfed wheat (Triticum aestivum L.) establishment under different tillage systems in Pothwar. Int. J. Plant Anim. Environ. Sci., 4: 146-154

Ashraf, M., M.A. Kahlown and A. Ashfaq, 2007. Impact of small dams on agriculture and groundwater development: a case study from Pakistan. Agric. Water Manage., 92: 90-98

Cardina, J., C.P. Herms and D.J. Doohan, 2002.Crop rotation and tillage system effects on weed seed banks. Weed Sci., 50: 448-460

Demjanova, E., M. Macak., I. Dalovic, F. Majernik, T. Stefan and S. Jozef, 2009. Effects of tillage systems and crop rotation on weed density, weed species composition and weed biomass in maize. Agron. Res., 7: 785-792
Devasenapathy, P., 2008. Efficiency Indices for Agriculture Management Research. New India Publishing Agency, New Delhi, India

Gencsoylu, I. and I. Yalcin, 2004. The effect of different tillage systems on cotton pests and predators in cotton fields. Asian J. Plant Sci., 3: 39-44

GOP, 2014. Economic Survey of Pakistan. Government of Pakistan, Ministry of Food and Agriculture, Islamabad, Pakistan

GOP, 2013. Federal Bureau of Statistics. Government of Pakistan, Islamabad, Pakistan

Gupta, O.P., 2011. Modern Weed Management, $4^{\text {th }}$ edition, pp: 523-532. Agrobios, Jodhpur, India

Hassannejad, S. and S.P. Ghafarbi, 2012. Introducing new indices for weed flora studies. Int. J. Agric. Crop. Sci., 4: 1653-1659

Hayat, R. and S. Ali, 2010. Contribution of water use efficiency of summer legumes for the production of rainfed wheat. Int. J. Agric. Biol., 12: 655-660

Jurado-Expósito, M., F. López-Granados, J.L. González-Andújar, L. Garc'ra-Torres, 2004. Spatial and temporal analysis of Convolvulus arvensis L. populations over four growing seasons. Eur. J. Agron., 21: $287-296$

Khan, I., A.U. Jan., F. Gul1, K. Ali, G. Ali, S. Ahmed and N. Ahmad, 2011. Weeds as a major constraint in wheat production in district Peshawar. Pak. J. Weed Sci. Res., 17: 381-386

Kobayashi, H., Y. Nakamura and Y. Watanabe, 2003. Analysis of weed vegetation of no-tillage upland fields based on the multiplied dominance ratio. Weed Biol. Manage., 3: 77-92

Konstantinović, B., M. Korać, N. Mandić, and M. Blagojević, 2011. Invasive weed species in ruderal and agriculture areas in Vojvodina. 22nd International symposium "Save food production" ,Trebinje, $401-403$.

Liebman, M., C.L. Mohler and C.P. Staver, 2001. Ecological Management of Agricultural Weeds. Cambridge University Press, Cambridge, UK

Naz, N., M. Hameed, M.S.A. Ahmad, M. Ashraf and M. Arshad, 2010. Soil salinity, the major determinant of community structure under arid environments. Commun. Ecol., 11: 84-90

Qureshi, R. and R. A. Memon, 2008.Weed communities of sunflower crop in Sukkur and Khairpur, Sindh: autumn aspect. Pak. J. Weed Sci. Res., 14: 43-53

Razzaq, A., M. Munir, N.I. Hashmi, P.R. Hobbs and A. Majid, 2002. Current management practices for wheat production in a rainfed agro-ecological zone in northern Punjab. Pak. J. Agric. Res., 17: 201-205

Rusu, T., P. Gus and I. Bogdan, 2006. The influence of minimum soil tillage systems on weed density, frequency of phytopatogenous agents and crop yields of soybean, wheat, potato, rape and corn. $J$. Food Agric. Environ., 4: 225-227

Rusu, T., P. Gus, I. Bogdan, L. Paulette and I. Oroian, 2013. Researches regarding to control species Convolvulus arvensis L. on relation with soil tillage systems. J. Central Eur. Agric., 7: 739-742

Stappers, R., K.J. Keesman and W. vander, 2003. The SAFE-RESULT Equations: an Agro-Forestry Model, p: 20. Technical Report, Oct. 2003, Wageningen University, The Netherlands

Steel, R.G.D., J.H. Torrie and D. Dickey, 1997. Principles and Procedure of Statistics. A Biometrical Approach 3rd Ed. McGraw Hill BookCo. Inc., New York, USA. pp. 352-358.

Usman, K.S., K. Khalil, F. Mohammad, M.A. Khan and A.Z. Khan, 2009. Weed management in wheat as affected by tillage and herbicides. Pak. J. Weed Sci. Res., 15: 155-169

Wiese, A.F., C.D. Salisbury, B.W. Bean, M.G. Schoenhals, and S. Amosson, 1996. Economic evaluation of field bindweed (Convolvulus arvensis) control in a winter wheat-fallow rotation. Weed Sci., 44: 622-628

(Received 01 January 2015; Accepted 15 April 2015) 